\title{
Multimodality, Cognition, and Experimental Literature
}

\section{Alison Gibbons}

Routledge
Taylor\& Francis Group
NEW YoRK LONDON 
First published 2012

by Routledge

711 Third Avenue, New York, NY 10017

Simultaneously published in the UK

by Routledge

2 Park Square, Milton Park, Abingdon, Oxon OX14 4RN

Routledge is an imprint of the Taylor \& Francis Group,

an informa business

(C) 2012 Taylor \& Francis

The right of Alison Gibbons to be identified as author of this work has been asserted by her in accordance with sections 77 and 78 of the Copyright, Designs and Patents Act 1988.

Typeset in Sabon by IBT Global.

Printed and bound in the United States of America on acid-free paper by IBT Global.

All rights reserved. No part of this book may be reprinted or reproduced or utilised in any form or by any electronic, mechanical, or other means, now known or hereafter invented, including photocopying and recording, or in any information storage or retrieval system, without permission in writing from the publishers.

Trademark Notice: Product or corporate names may be trademarks or registered trademarks, and are used only for identification and explanation without intent to infringe.

Library of Congress Cataloging-in-Publication Data

A catalog record has been requested for this book.

ISBN13: 978-0-415-87361-1 (hbk)

ISBN13: 978-0-203-80321-9 (ebk) 
This is it. 


\section{Contents}

List of Figures $\quad$ ix

Permissions xi

Acknowledgements xiii

1 Introduction 1

2 Multimodality 1

3 Towards a Multimodal Cognitive Poetics 26

4 Crossing Thresholds and the Exploring Reader of House of Leaves by Mark Z. Danielewski 46

5 Embodiment and the Book that Bleeds: VAS: An Opera in Flatland by Steve Tomasula with Stephen Farrell 86

6 Cowitnessing Trauma in Reading Extremely Loud \& Incredibly Close by Jonathan Safran Foer

7 Cut, Paste, Repair, but Read: Woman's World by Graham Rawle 167

8 Conclusion 208

$\begin{array}{ll}\text { Appendix A } & 227\end{array}$

Appendix B 231

References 233

Index 251 